\title{
Analysis of Factors Affecting the Unmet Need Incidence in Couples of Childbearing Age in the West Bulotadaa Village Gorontalo City in 2019
}

\author{
Mayangsari Kau ${ }^{1}$, A. Ummu Salmah ${ }^{2 *}$, Anwar Mallongi ${ }^{3}$, Muhammad Arif Tiro ${ }^{4}$ \\ ${ }^{1}$ Department of Biostatistics, Faculty of Public Health, Hasanuddin University, Makassar, Indonesia; ${ }^{2}$ Department of Reproduction \\ Health, Faculty of Public Health, Hasanuddin University, Makassar, Indonesia; ${ }^{3}$ Department Statistics Study Program, Faculty \\ of Mathematics and Natural Sciences, Makassar, Indonesia; ${ }^{4}$ Department of Environmental Health, Faculty of Public Health, \\ Hasanuddin University, Makassar, Indonesia
}

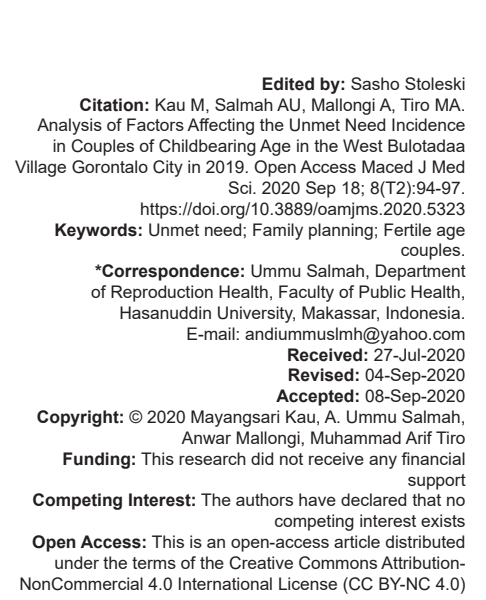

\begin{abstract}
BACKGROUND: Population that continues to increase is a big problem for countries in the world, especially developing countries. One of the problems in the management of family planning programs is the high level of unmet need for family planning in Indonesia. Unmet need is the number of couples of childbearing age who want to postpone pregnancy or do not want additional children but do not use birth control methods.

AIM: The aim of the study was to determine the determinants of the occurrence of unmet need in fertile age couples in the West Bulotadaa Village, Gorontalo City.

METHODS: The study design was cross-sectional with a sample of 146 fertile age couples selected by systematic random sampling. Data collection was made, using questionnaires containing questions from the research variables. Data were analyzed by multiple logistic regression analysis through the SPSS for windows program.

RESULTS: The visit of KB officers affected the unmet need with $p=0.032(p<0.05)$ with $O R=2.893$, and there were some variables that were not significant such as the age variable $p=0.766(p>0.05)$, family income $p=0.189$ $(p>0.05)$, distance of family planning services $p=0.057(p>0.05)$, and cost of contraception $p=0.632(p>0.05)$. CONCLUSION: It was concluded that the visit of family planning officers affected the unmet need and age, family income, distance to the place of family planning services and the cost of contraceptives did not affect the incidence of unmet need in West Bulotadaa, Gorontalo City.
\end{abstract}

\section{Introduction}

Realizing the highest degree of maternal health is one of the development agendas covered by the health component's sustainable development goals development objectives, namely, achieving universal access to reproductive health services. There are four parameters used to assess access to reproductive health services, namely, active participation in family planning contraceptive prevalence rate (CPR), birth rates in adolescent girls aged 15-19 years ago [1].

Recent data on unmet needs in the Pakistan Demographic and Health Survey revealed a CPR of $29.6 \%$, where the use of modern methods was only $21.7 \%$. On the other hand, $55 \%$ of women want to use family planning, but family planning services and programs fail to meet demand and result in unmet needs of 25\% [2]. Unmet need and CPR will affect TFR, which in turn will affect maternal mortality rate. Unmet need can have an impact on the occurrence of KTD, which is high in Indonesia [3].
Unmet need for family planning is a multidimensional problem because it is influenced by various factors such as demographic, socio-economic characteristics, attitudes, and service access. In general, unmet need for family planning is common among women who face financial, educational, geographical, and social barriers. Other factors in the community, such as culture, service quality, presence of transportation routes, and regional characteristics play a role in the use of contraceptives [4]. The Gorontalo Province is one of the provinces with a greater percentage of provincial unmet needs than national unmet needs. Where the percentage of national unmet need is $10.6 \%$, which is divided into thinning categories by $6.5 \%$ and restrictions as much as $4.1 \%$ while the province of Gorontalo the percentage of unmet need is $12.9 \%$ which is divided into thinning categories by $3.9 \%$ and restrictions at $9.15 \%$ [5].

Based on data from the BKKBN Gorontalo Province in 2019, regencies or cities with the highest unmet need figures are in Gorontalo City at $13.6 \%$ and the lowest was in Boalemo Regency with $5.8 \%$. 
Furthermore, in Gorontalo City the highest unmet need number was in Sipatana sub-district with $21.9 \%$ with the highest percentage of Unmet need village occurring in West Bulotadaa Village at $57.4 \%$ and the lowest was in Molosipat $U$ village at 4\% [6].

The high number of unmet need in Gorontalo City compared to other districts in Gorontalo Province is $13.6 \%$ in 2019. Sipatana sub-district is the highest subdistrict with a percentage of unmet need of $21.9 \%$ and village with the highest unmet need percentage are in West Bulotadaa Village is $57.4 \%$, so this study aims to determine the determinants of unmet need in the West Bulotadaa Village Gorontalo City.

\section{Materials and Methods}

This research is an observational analytic study and the design used was cross-sectional study. This research was conducted from October 2019 to November 2019 in Bulotadaa Barat Village, Sipatana District, Gorontalo City.

The population in this study was all couples of childbearing age group of 15-49 years old and recorded at the Family Planning Center of West Bulotadaa Village in 2019 amounted to 705 couples of childbearing age. The sample of this research is 146 fertile age couples with a systematic random sampling technique.

Collection is done by distributing questionnaires that contain questions related to the research variables given to respondents selected as research samples in Kelurahan Bulotadaa Barat Gorontalo City.

Analysis techniques of this study used univariate analysis, bivariate analysis with test Chisquare and multivariate analysis with multiple logistic regressions in the SPSS for Windows Program.

\section{Results}

Table 1 shows the characteristics of respondents consisting of age, education, and occupation. The majority of respondents in the age group of $>35$ years were 71 respondents $(48.6 \%)$, while five respondents $(3.4 \%)$ were in the age group of $<20$ years. For education variables, the most respondents were elementary school education by 50 respondents $(34.2 \%)$, while the fewest respondents with D3 education were one respondent $(0.7 \%)$. Job variable shows that most respondents are non-employed/IRT respondents, namely, 105 respondents $(71.9 \%)$, while the least number of respondents who work as farmers are one respondent $(0.7 \%)$.
Table 1: Characteristics of respondents in the district of West Bulotadaa

\begin{tabular}{lll}
\hline Characteristics & $\mathrm{n}$ & $\%$ \\
\hline Age (years) & & \\
$<20$ & 5 & 3.4 \\
$20-35$ & 70 & 47.9 \\
$>35$ & 71 & 48.6 \\
Education of respondents & 50 & 34.2 \\
$\quad$ Elementary school & 34 & 23.3 \\
Middle school & 43 & 29.5 \\
High school & 1 & 0.7 \\
D3 & 16 & 11.0 \\
S1 & 2 & 1.4 \\
S2 & 13 & 8.9 \\
Work & 105 & 71.9 \\
Private & 15 & 10.3 \\
IRT & 10 & 6.8 \\
Trader & 2 & 1.4 \\
Civil servants & 1 & 0.7 \\
Labor & & \\
Farmers & & \\
\hline
\end{tabular}

Table 2 shows the distribution of respondents based on research variables. The distribution of respondents based on events unmet need, the majority of respondents who met need were 91 $(62.3 \%)$ while respondents with unmet needs were 55 (37.7\%). The age distribution of respondents mostly in the risk age group is 76 respondents (52.1\%), while the respondents in the age group are not at risk as many as 70 respondents $(47.9 \%)$. The distribution of family income to respondents is mostly on high family income, as many as 101 respondents (69.2\%), while respondents with low education are 45 respondents $(30.8 \%)$. The distribution of family planning visits by respondents to most respondents who had never been visited was 112 respondents (76.7\%), while respondents who had been visited were 34 respondents $(23.3 \%)$. Distribution of distance to family planning services, the majority of respondents who are close to family planning services are 134 respondents $(91.8 \%)$, while respondents who live far from family planning services are 12 respondents $(8.2 \%)$. The cost distribution of contraceptives to most respondents is the cost of affordable contraceptives as many as 142 respondents (97.3\%), while respondents who are not affordable contraception costs are four respondents $(2.7 \%)$.

Table 2: Distribution of respondents by research variables in West Bulotadaa village

\begin{tabular}{lll}
\hline Variable & Amount (n) & Percentage (\%) \\
\hline Unmet need incident & & \\
$\quad$ Unmet need & 55 & 37.7 \\
$\quad$ Met need & 91 & 62.3 \\
Age & & \\
$\quad$ Risky & 76 & 52.1 \\
$\quad$ No risk & 70 & 47.9 \\
Family income & & \\
$\quad$ Low & 101 & 69.2 \\
$\quad$ High & 45 & 30.8 \\
Visit of KB Officers & 112 & 76.7 \\
$\quad$ Never & 34 & 23.3 \\
$\quad$ Ever & 12 & 8.2 \\
Distance of KB services & 134 & 91.8 \\
$\quad$ Far & & \\
$\quad$ Close & 4 & 2.7 \\
Cost of contraception & 142 & 97.3 \\
$\quad$ Unreachable & & \\
$\quad$ Affordable & &
\end{tabular}

Table 3 shows the distribution of respondents based on research variables on the occurrence of 
Table 3: Factors affecting unmet need in fertile age couple village West Bulotadaa

\begin{tabular}{|c|c|c|c|c|c|c|c|}
\hline \multirow{3}{*}{ Variable } & \multicolumn{6}{|c|}{ Unmet need KB } & \multirow[t]{3}{*}{$\mathrm{p}$ value } \\
\hline & \multicolumn{2}{|c|}{ Unmet need } & \multicolumn{2}{|c|}{ Met need } & \multicolumn{2}{|c|}{ Amount } & \\
\hline & $\mathrm{n}$ & $\%$ & $\mathrm{n}$ & $\%$ & $\mathrm{n}$ & $\%$ & \\
\hline \multicolumn{8}{|l|}{ Age } \\
\hline Risky & 30 & 39.5 & 46 & 60.5 & 76 & 100.0 & 0.766 \\
\hline No risk & 25 & 35.7 & 45 & 64.3 & 70 & 100.0 & \\
\hline \multicolumn{8}{|l|}{ Family Income } \\
\hline Low & 34 & 33.7 & 67 & 66.3 & 101 & 100.0 & 0.189 \\
\hline High & 21 & 46.7 & 24 & 53.3 & 45 & 100.0 & \\
\hline \multicolumn{8}{|c|}{ Visit of KB officers } \\
\hline Never & 48 & 42.9 & 64 & 57.1 & 112 & 100.0 & 0.032 \\
\hline Ever & 7 & 20.6 & 27 & 79.4 & 34 & 100.0 & \\
\hline \multicolumn{8}{|c|}{ Distance of KB service area } \\
\hline Far & 8 & 66.7 & 4 & 33.3 & 12 & 100.0 & 0.057 \\
\hline Close & 47 & 35.1 & 87 & 64.9 & 134 & 100.0 & \\
\hline \multicolumn{8}{|c|}{ Cost of contraception } \\
\hline Unreachable & 2 & 50.0 & 2 & 50.0 & 4 & 100.0 & 0.632 \\
\hline Affordable & 53 & 37.3 & 89 & 62.7 & 142 & 100.0 & \\
\hline
\end{tabular}

unmet need. Unmet need occurs more at risk age groups ( $<20$ years and $>35$ years) that is as many as 30 respondents $(39.5 \%)$ compared to those who are not at risk (20-35 years), i.e., as many as 25 respondents $(35.7 \%)$ with a value of $p>0.05$. Unmet need is more common in respondents with low family income as many as 34 respondents $(33.7 \%)$ compared to respondents with high family income, as many as 21 respondents $(46.7 \%)$ with a value of $p>0.05$. Unmet need is more common in groups that have never been visited by family planning officers, as many as 48 respondents (42.9\%) compared to groups of respondents who have been visited, as many as seven respondents $(20.6 \%)$ with a value of $p<0.05$. Unmet need is more common in groups where respondents are close to family planning services, namely, 47 respondents (35.1\%) compared to the group of respondents who have been visited, as many as 8 respondents $(66.7 \%)$ with a value of $p>0.05$. Unmet need is more common in the group that is affordable by the cost of contraceptives as many as 53 respondents $(37.3 \%)$ compared to the group that is not affordable by contraception costs which is as much as two respondents $(50.0 \%)$. with a value of $p>0.05$

Table 4 shows the conclusions of multivariate analysis with multiple logistic regressions. Of thefive independent variables included in the test simultaneously only family planning visits by the staff of consistent significance. Hence, it can be concluded that the visit of family planning officers with an $O R$ value of $2.893>1$ is a risk factor with a lower-upper value = 1.163-7.199, which means couples of childbearing age who have not received family planning visits during the past 6 months have the possibility of 2893 times greater unmet need for KB compared to couples of childbearing age who have been visited by family planning officers in the past 6 months.

Table 4: Multivariate analysis of unmet need events in the West Bulotadaa Village

\begin{tabular}{|c|c|c|c|c|c|c|}
\hline \multirow[t]{2}{*}{ Variable } & \multirow[t]{2}{*}{$\mathrm{B}$} & \multirow[t]{2}{*}{ Df } & \multirow[t]{2}{*}{$p$ value } & \multirow[t]{2}{*}{ OR } & \multicolumn{2}{|c|}{$95 \% \mathrm{Cl}$ for exp. (B) } \\
\hline & & & & & Lower & Upper \\
\hline Visit of family planning officers & 1,062 & 1 & 0.022 & 2.893 & 1.163 & 7.199 \\
\hline
\end{tabular}

\section{Discussion}

This study shows that the visit of a family planning officer in the West Bulotadaa Village affected the unmet need incident. Most respondents have not been visited by family planning staff during the past 6 months; so many couples of childbearing age do not get more information about family planning, especially for the prevention of side effects of birth control. In addition, most respondents who were not at home were also the reason that respondents felt they had never been visited so that when family planning officers came to deliver information to couples of childbearing age, they were outside the home.

This research is in line with research conducted by Ayuningtyas et al. [7] in NTB which suggested that the visit of family planning staff was a factor influencing the unmet need. This study is not in line with research conducted by Sulikhah et al. (2016) in Purworejo Regency which suggested that the visit of health workers was not related to the unmet need for family planning in Purworejo.

This study also shows that age, family income, distance to family planning services, and the cost of contraception do not affect the incidence of unmet need in West Bulotadaa Village. For age variables, respondents assume that at age $<20$ years are too young to use contraception and there is a prohibition on husbands to use contraception at a too young age. While at the age of $>35$ years, many respondents assume that it is no longer a reproductive period and consider themselves to be old so that the possibility of pregnancy occurring is very small. This study is in line with research conducted by Sariyati et al. [8] in Yogyakarta which suggests that there is no significant relationship between wife's age and unmet need. Other research also conducted by Nzokirishaka and Itua [9] in Burudi suggested that younger ages (18-24 years) had higher needs that were not met for family planning.

For the family income variable, low family income is not a factor of unmet need childbearing age, this is because the cost of contraceptives in West Bulotadaa is affordable, and even many can use BPJS to the Puskesmas to get free contraception. Thus, income is not a factor influencing fertile age couples for the utilization of health services in the West Bulotadaa Village. In addition, the distance to family planning services in this case the Puskesmas is close enough to be reached on foot so that there is no need to ride a public vehicle (bentor and motorcycle taxi) to incur costs.

This research is not in line with research conducted by Ayuningtyas et al. [7] in West Nusa Tenggara which suggests that income levels can affect the unmet need for family planning through various means, such as disagreement about contraception, inadequate information, and financial problems in daily 
needs. Other research was also conducted by Uljannah et al. [10] who suggested that income was not related to unmet need events in Adiwerna Village.

For the variable distance to family planning services, the distance from the respondent's house to family planning services in this case the Puskesmas is close enough to be walked on foot $<2 \mathrm{~km}$ so there is no need to ride a public vehicle (bikes and motorcycle taxi). Many people choose to walk to the family planning service. However, the close distance is not a preventative factor for a person who does not need unmet; this can be seen that more respondents distance from the respondent's house to a family planning service location is close but still choose not to use contraception (unmet need). This is caused by the lack of family planning staff visits to socialize family planning. The family planning center is more focused on implementing posyandu and rarely does counseling related to contraception. Respondents' fear of side effects also requires counseling from PLKB cadres and local health centers. This study is not in line with research conducted by Eliason et al. [11] in Ghana which suggests that distance to health facilities affects unmet need for family planning in Ghana.

For the variable cost of contraception, the results of this study found that affordable or low costs are not a guarantee that women will use contraception [12], [13]. There are still other factors that determine whether a woman will use contraception or not. Government programs that make contraceptive costs cheaper seem to have not been very successful in handling unmet need for family planning in the West Bulotadaa Village when viewed from the results of the above research. Most of the respondents use BPJS for free but the collaboration between the government and family planning officers is still lacking in providing information about the family planning itself. This study is in line with research conducted by Putro and Listyaningsih [14] which suggests that the cost of contraceptives does not have a significant effect on the incidence of unmet need for family planning.

\section{Conclusion}

It was concluded that the visit of family planning officers affected the unmet need and age, family income, distance to the place of family planning services and the cost of contraceptives did not affect the incidence of unmet need in West Bulotadaa, Gorontalo City.

\section{Recommendation}

It is expected that the government, family planning field officers and health workers will work together to give more attention to visits every 6 months, especially for socialization related to the use of contraception to reduce the prevalence of unmet need.

\section{References}

1. Kemenkes RI. Riset Kesehatan Dasar 2013. Jakarta: Kementrian Kesehatan Republik Indonesia; 2013.

2. Sulikhah S, Nugroho D. dan Dharmawan Y. Hubungan beberapa faktor pasangan usia subur (PUS) dengan unmet need keluarga berencana (KB) di desa penungkulan kecamatan gebang kabupaten purworejo. J Kesehatan Masyarakat. 2017;5(4):26573. https://doi.org/10.33490/jkm.v4i1.64

3. Fadhila NH, Ratno W, Fauziah E. Unmed need keluarga berencana pada pasangan usia subur di kecamatan padang barat tahun 2015. J Kesehatan Masyarakat Andalas. 2016;10(2):1516. https://doi.org/10.24893/jkma.10.2.151-156.2016

4. Katulistiwa R, Ni'mal B, Dwi MW. Determinan unmet need KB pada wanita menikah di kecamatan klabang kabupaten Bondowoso (determinants for family planning among married women at klabang sub district in Bondowoso). J Pustaka Kesehatan. 2014;2(2):277-84.

5. SDKI. Data Kejadian Unmet Need di Indonesia. Jakarta: Survei Demografi Kesehatan Indonesia; 2017.

6. BKKBN. Laporan Pengumpulan Data Keluarga. Gorontalo: Badan Kependudukan Keluarga Berencana Nasional; 2019. https://doi.org/10.24329/aspikom.v2i4.75

7. Ayuningtyas D, Oktaviana W, Misnaniarti M. Factors contributing to unmet need for contraception in Nusa Tenggara Barat, Indonesia. J Reprod Contracept. 2015;26(4):239-48.

8. Sariyati $S$, Mulyaningsih S, Sugiharti S. Faktor-faktor terkait belum terpenuhinya kebutuhan KB pada pasangan usia subur di kota Yogyakarta. J Perawat Kebidanan Indones. 2015;3(3):1238. https://doi.org/10.21927/jnki.2015.3(3).123-128

9. Nzokirishaka A, Itua I. Determinants of unmet need for family planning among married women of reproductive age in Burundi: A cross-sectional study. Contracept Reprod Med. 2018;3(1):11. https://doi.org/10.1186/s40834-018-0062-0 PMid:29951222

10. Uljanah $\mathrm{K}$, Winarni $\mathrm{S}$, Mawarni $\mathrm{A}$. Hubungan faktor risiko kejadian unmet need KB (keluarga berencana) di desa adiwerna, kecamatan adiwerna, kabupaten tegal, triwulan III. J Kesehatan Masyarakat. 2016;4(4):204-12.

11. Eliason S, John K, Williams A, Cecilia E, Jacob N, Justice N, et al. Determinants of modern family planning use among women of reproductive age in the Nkwanta district of Ghana: A case-control study. Reprod Health. 2014;11(1):65. https://doi. org/10.1186/1742-4755-11-65

PMid:25117887

12. Muhith A, Winarti E, Perdana SS, Haryuni S, Rahayu KI, Mallongi A. Internal locus of control as a driving factor of early detaction behavior of servical cancer by inspection visual of acetic acid method. Open Access Maced J Med Sci. 2020;8:1136. https://doi.org/10.3889/oamjms.2020.4341

13. Mallongi A, Birawida AB, Astuti RD, Saleh M. Effect of lead and cadmium to blood pressure on communities along coastal areas of Makassar, Indonesia. Enferm Clin. 2020;30(4):313-7. https:// doi.org/10.1016/j.enfcli.2020.03.001

14. Putro DA, Listyaningsih U. Kebutuhan belum terpenuhi untuk keluarga berencana di wilayah perkotaan dan pedesaan di provinsi daerah istimewa Yogyakarta. J Bumi Indones. 2017;6(4):1-10. https://doi.org/10.21831/gm.v15i1.16233 